\title{
STUDI KELAYAKAN INVESTASI BISNIS PROPERTI
}

(Studi Kasus: PT. Gowa Makassar Tourism Development Tbk)

\author{
Ryan Gunawan \\ Institut Bisnis dan Keuangan Nitro Makassar \\ Email : ryangunawann4@gmail.com
}

\begin{abstract}
ABSTRAK
Sudah sejak lama pemerintah (regulator), pengembang (pelaksana) dan pihak perbankan (sumber pendanaan), terjebak dalam salah kaprah dalam melihat bisnis properti. Anggapan pemerintah, pembangunan kawasan perumahan skala besar (melalui dalih pembangunan kota baru atau kota mandiri) akan menciptakan efisiensi pada industri perumahan nasional, ternyata keliru total. Begitu juga dengan pandangan yang terbukti salah dari pihak pengembang dan perbankan yang menganggap dari kalkulasi bisnis, proyek properti skala besar akan lebih menguntungkan ketimbang proyek skala kecil. Logikanya, semakin besar proyek properti akan semakin tinggi harga tanah dan harga rumah dijual ke pasar (konsumen) dan semakin kecil pula pangsa pasarnya.

Mengingat proyek PT Gowa Makassar Tourism Development merupakan produk properti yang telah diluncurkan sejak tahun 1997 dan mempertaruhkan modal besar dalam jangka panjang maka akan timbul masalah apakah menginvestasikan dana pada PT Gowa Makassar Tourism Development menguntungkan atau tidak. Dalam menganalisis data-data dan hasil penelitian, peneliti menggunakan analisa NPV, analisa IRR, analisa dan profitability indeks.

Berdasarkan hasil penelitian proyek, maka didapatkan NPV yang diperoleh adalah Rp. 33.945.769.876,- yang menunjukkan bahwa proyek ini layak untuk dijalankan. Hasil IRR yang diperoleh adalah $27,26 \%>13,63 \%$, maka hal ini menunjukkan proyek ini layak untuk dijalankan.
\end{abstract}




\section{PENDAHULUAN}

Peringatan Bapak Gubernur Bank Indonesia, apabila dana jangka pendek perbankan digunakan untuk keperluan investasi jangka panjang di sektor properti, maka terjadi mismatch. Begitu juga dengan pengamat properti Bapak Panangian Simanungkalit yang mengingatkan prilaku pengembang yang terlampau rakus dalam melakukan ekspansi di dunia bisnis properti. Sudah sejak lama pemerintah (regulator), pengembang (pelaksana) dan pihak perbankan (sumber pendanaan), terjebak dalam salah kaprah dalam melihat bisnis properti. Anggapan pemerintah, pembangunan kawasan perumahan skala besar (melalui dalih pembangunan kota baru atau kota mandiri) akan menciptakan efisiensi pada industri perumahan nasional, ternyata keliru total. Begitu juga dengan pandangan yang terbuti salah dari pihak pengembang dan perbankan yang menganggap dari kalkulasi bisnis, proyek properti skala besar akan lebih menguntungkan ketimbang proyek skala kecil. Logikanya, semakin besar proyek properti akan semakin tinggi harga tanah dan harga rumah dijual ke pasar (konsumen) dan semakin kecil pula pangsa pasarnya. Untuk menggairahkan kembali perekonomian nasional, tidak ada cara lain kecuali mengundang investor baru bahkan kalau perlu investor asing masuk karena hampir semua kegiatan pembangunan saat ini sudah dibiayai lembaga keuangan internasional, begitu juga di sektor properti.

Proyek PT Gowa Makassar Tourism Development merupakan produk properti yang telah diluncurkan sejak tahun 1997 dan mempertaruhkan modal besar dalam jangka panjang. Peneliti menetapkan pokok masalah yang dibahas adalah apakah menginvestasikan dana pada Ciater Riung Rangga menguntungkan atau tidak. Dalam menganalisis data-data dan hasil penelitian, peneliti menggunakan analisa NPV, analisa IRR, dan analisa profitability indeks. Pada studi ini, akan dilihat prospek proyek PT Gowa Makassar Tourism Development agar dapat digunakan sebagai pedoman perencanaan dalam pengambilan keputusan, baik bagi developer, investor atau pemberi bantuan kredit dan lembaga lain yang berhubungan dengan kegiatan proyek tersebut dan sebagai pedoman dalam pengawasan apakah proyek nanti dapat berjalan sesuai dengan yang direncanakan atau tidak. 


\section{TINJAUAN PUSTAKA}

\section{Investasi}

Teori ekonomi mengartikan atau mendefinisikan investasi sebagai pengeluaran untuk membeli barang - barang modal dan peralatan - peralatan produksi dengan tujuan untuk mengganti dan terutama untuk menambah barang - barang dan jasa di masa depan. Investasi yang lazim disebut dengan istilah penanaman modal atau pembentukan modal. Menurut Jogiyanto (2012), investasi adalah penundaan konsumsi sekarang untuk dimasukkan ke aktiva yang produktif selama periode tertentu. Adanya aktiva yang produktif tersebut akan meningkatkan utiliti total.

\section{Capital Budgeting}

Capital budgeting adalah keseluruhan proses perencanaan dan pengambilan keputusan mengenai pengeluaran dana dimana jangka waktu kembalinya dana tersebut melebihi waktu satu tahun. (Syamsuddin, 2009:412-413). Pengeluaran ini termasuk untuk pembelian aset tetap yaitu tanah, bangunan, mesin - mesin, dan pengeluaran dana untuk proyek advertensi jangka panjang, penelitian dan pengembangan. Berdasarkan pendapat tersebut capital budgeting dapat diartikan sebagai keputusan investasi jangka panjang yang memerlukan pengevaluasian, penyeleksian dan pengujian karena menyangkut pengeluaran modal besar.

Teknik - teknik capital budgeting, teknik yang digunakan penilaian kelayakan investasi ini disebut dengan teknik capital budgeting, adapun penjelasannya sebagai berikut :

a. Metode Net Present Value (NPV)

Net present value (NPV) suatu proyek adalah selisih dari present value of proceeds dengan $P V$ of initial investment selama umur ekonomisnya berada pada discount rate tertentu.

b. Metode Internal Rate Of Return (IRR)

Internal rate of return (IRR) adalahmetode yang menghitungtingkatbunga (discount rate) yang membuat nilai sekarang dari seluruh perkiraan arus kas masuk sama dengan nilai sekarang dari ekspektasi arus kas keluar (Hazen, 2009)

c. Profitability Index (PI)

Yaitu menghitung perbandingan Present Value of Cash Inflow dengan Initial Investment.

\section{Kelayakan Investasi}


Analisis kelayakan investasi merupakan kegiatan yang berhubungan dengan perkiraan, penafsiran, dan peramalan dari berbagai kemungkinan di masa yang akan datang. Menurut Kasmir dan Jakfar (2010:60) peramalan atau prediksi merupakan kegiatan untuk memperkirakan apa yang akan terjadi di masa yang akan datang pada saat sekarang. Menurut kasmir dan Jakfar (2015:7) kelayakan artinya penelitian yang dilakukan secara mendalam tersebut dilakukan untuk menentukan apakah usaha yang akan dijalankan akan memberikan manfaat yang lebih besar dibandingkan dengan biaya yang dikeluarkan. Layak disini diartikan juga akan memberikan keuntungan tidak hanya bagi perusahaan yang menjalankannya, tetapi juga bagi investor, kreditur, pemerintah, dan masyarakat luas. Investasi pada perusahaan mengharapkan kelayakan pada perusahaan akan memperoleh kembali biaya yang di investasikan dalam jangka waktu yang cukup lama.

\section{Teori Evaluasi Proyek}

Proyek merupakan suatu rangkaian aktivitas yang dapat direncanakan, yang didalamnya menggunakan sumber-sumber (inputs), misalnya : uang dan tenaga kerja, untuk mendapat manfaat (benefits) atau hasil (return) di masa yang akan datang (Kadariah, Lien Karlina, Glive Gray, Pengantar Evaluasi Proyek, hal 1).

Kegunaan evaluasi proyek adalah untuk menganalisa terhadap suatu proyek tertentu, baik proyek yang akan dilaksanakan, sedang dan selesai dilaksanakan untuk bahan perbaikan dan penilaian pelaksanaan proyek tersebut.

\section{Dasar Pertimbangan Keputusan Proyek}

Dasar Pertimbangan Keputusan Proyek Dalam suatu Negara yang sedang membangun selalu dibutuhkan kegiatan-kegiatan seperti proyek. Dengan adanya proyek-proyek tersebut, pendapatan suatu Negara (terutama Negara yang sedang membangun) diharapkan dapat meningkat. Investasi (investment) dibagi menjadi :

a. Autonomous Investment, yaitu suatu investasi yang tidak dipengaruhi oleh tingkat pendapatan. $(\mathrm{I}=\mathrm{I} 0)$

b. Induce Investment, yaitu suatu investasi yang mempunyai kaitan dengan tingkat pendapatan. $(\mathrm{I}=\mathrm{f}(\mathrm{Y}))$

c. Investasi yang sifatnya dipengaruhi oleh adanya tingkat bunga uang atau modal yang berlaku di masyarakat. $(I=f(r))$ 
Untuk mengambil keputusan apakah suatu investasi akan diterima atau tidak, berdasarkan pada besarnya keuntungan dan biaya yang dikeluarkan, dimana keuntungan harus lebih besar daripada biayanya.

\section{Aspek-aspek Perencanaan Evaluasi Proyek}
a. Aspek Teknis
b. Aspek Managerial, Organisasi dan Institusi/Lembaga
c. Aspek Sosial
d. Aspek Ekonomis
e. Aspek Finansial

\section{Metode Penilaian Investasi}

1. Metode NPV (Net Present Value)

Merupakan metode analisis keuangan yang memperhatikan adanya perubahan nilai uang karena faktor waktu; proyeksi arus kas dapat dinilai sekarang (periode awal investasi) melalui pemotongan nilai dengan faktor pengurang yang dikaitkan dengan biaya modal (persentase bunga).

$$
\mathrm{NPV}=\text { Total PV AliranKasBersih - Total PV Investasi }
$$

Kriteria penilaian NPV adalah :

○ Jika NPV $>0$, maka investasi diterima.

○ Jika NPV $<0$, maka investasi ditolak.

2. Internal Rate of Returns (IRR)

Merupakan tingkat bunga yang menggambarkan bahwa antara benefit (penerimaan) yang telah dipresent-valuekan dan cost (pengeluaran) yang telahdipresent-valuekanadalahsamadengan nol.

$$
\begin{aligned}
\mathrm{IRR}= & \mathrm{ib}+\underline{\mathrm{NPVib}}(\mathrm{ib}-\mathrm{ik}) \\
& \text { NPVib }
\end{aligned}
$$

3. Metode PI (Profitabilitas Indeks)

Indeks profitabilitas adalah rasio atau antara jumlah nilai sekarang arus kas selama umur ekonomisnya dan pengeluaran awal proyek. Total PV Kas Bersih PI = Total Investasi Kriteria untuk Profitabilitas Indeks : 
o Proyek dinilai layak jika PI $>$ atau $=1,00$, sebaliknya

o Dinilai tidak layak jika PI $<1,00$

\section{HASIL PENELITIAN DAN PEMBAHASAN}

\section{Hasil penelitian}

\section{a. Metode NPV (Net Present Value)}

Kriteriapenilaian NPV adalah:

- Jika NPV positif maka investasi diterima

- Jika NPV negative maka investasiditolak

Penghasilan 2019 - penghasilan $2018 \times 100 \%$

Penghasilan 2019

$=\underline{\text { Rp. } 45.553 .332 .893-\text { Rp. } 39.343 .296 .619} \times 100 \%$

Rp. $\underline{45.553 .332 .893}$

$=13,63 \%$

2018 : Rp. $467.746 .263 .941=$ Rp. 31.971 .720 .023

$$
(1+13,63)^{1}
$$

2019:Rp.473.888.367.031 =Rp. 2.214.049.853

$$
(1+13,63)^{2}
$$

Jumlah OC adalah: Rp. 34.185.769.876

$$
\begin{aligned}
\mathrm{NVP} & =\sum o c-\mathrm{IO} \\
& =\text { Rp.34.185.769.876- Rp. } 240.000 .000 \\
& =\text { Rp.33.945.769.876 }
\end{aligned}
$$

Hasil uji analisis dengan metode NPV menunjukkan hasil positif sebesar Rp. 33.945.769.876. Dengan hasil demikian karena nilai NPV positif maka proyek tersebut diterima dan layak untuk dilakukan.

\section{b. Metode PI (Profitability Index)}


Kriteria penilaian profitability index adalah:

- $\quad$ Proyek dinilai layak jika PI >atau $=1,00$

- Proyek dinilai tidak layak jika PI $<1,00$

$$
P I=\frac{\sum c o}{I O}=\frac{34 \cdot 185.769 .876}{240.000 .000}=142,44
$$

Hasil uji analisis dengan metode PI (Profitability Index) menunjukkan hasil 142,44. Dengan demikian investasi layak dilakukan.

\section{c. Metode IRR}

$$
\begin{aligned}
\mathrm{IRR} & =\mathrm{ib}+\frac{N P V i b}{N P V i b}(i b-i k) \\
& =13,63 \%+\frac{33.945 .769 .876}{33.945 .769 .876}(13,63-0) \\
& =13,63 \%+13,63 \% \\
& =27,26 \%
\end{aligned}
$$

Hasil dari metode IRR menunjukkan hasil 27,26\% yang lebih tinggi dari persen yang ditargetkan yaitu 13,63\%. Dengan itu proyek investasisebaiknya diterima karena layak untuk dilakukan. 


\section{KESIMPULAN}

Berdasarkan hasil penelitian proyek pada bab sebelumnya, maka dapat ditarik kesimpulan sebagai berikut :

1 NPV : Rp33.945.769.876,-. NPV yang diperoleh adalah NPV positif, hal ini menunjukkan bahwa proyek ini layak untuk dijalankan.

2 IRR :27,26\%. IRR yang diperoleh adalah IRR $>$ Discount Rate $(27,26 \%>13,63 \%)$, halinimenunjukkanproyekinilayakuntukdijalankan.

Dengan demikian proyek PT.Gowa Makasssar Tourism Development ini layak untuk dijalankan dan menginvestasikan dana pada proyek ini adalah menguntungkan dan mempunyai prospek yang cukup bagus.

Dari analisis di atas yang paling baik adalah Analisa NPV yang juga memperhatikan rate of return atau cost of capital yang diinginkan selain time of money. Studi Real Estate adalah studi yang komplek dan memerlukan beberapa disiplin ilmu, tergantung dari tipe real estate. 


\section{DAFTAR PUSTAKA}

Kadariah, K.L. dan Gray, G. Pengantar Evaluasi Proyek, Lembaga Penerbitan FE-UI.

Pudjosunarto, M. Evaluasi Proyek, Penerbit Liberty, Yogyakarta.

Riyanto, B. Dasar-dasar Pembelanjaan Perusahaan, Yayasan Penerbit Gadjah Mada, Yogyakarta.

Suwarto Fx. dan Wisnu, Fx. Pengantar Manajemen Keuangan, Penerbit Univ. Atma Jaya, Yogyakarta.

Gray, C., Subur, L.K., Simanjuntak, P., dan Maspaitella, P.F.L. Pengantar Evaluasi Proyek, Penerbit PT. Gramedia, Jakarta.

Husnan, S. dan Suwarsono. Studi Kelayakan Proyek, Lembaga Penerbitan FE-UI.

Chang, J., Indrajaja, G. dan Santoso, B. 1998. Strategi Pemasaran Real Estate, School of Real Estate, Cetakan Pertama, November.

Mutaqin, M.A. 1998. Riset Pasar Real Estate, School of Real Estate, Cetakan Pertama.

Danuza, O. 1998. Appraisal Properti, School of Real Estate, Cetakan Pertama.

Dent, H.S. 1993. The Great Boom Ahead, Vision Publishing.

Minkin, B.H. 1993. Econoquake, Vision Publishing.

Somers, J. 1993. Building Wealth Through Investment Property, Vision Publishing. 